\title{
ERRATUM
}

\section{LIMITED ASSET MARKET PARTICIPATION AND DETERMINACY IN THE OPEN ECONOMY - ERRATUM}

\section{EdWARD F. BufFIE AND LuIS-Felipe ZanNA}

https://doi.org/10.1017/S1365100516000961, Published by Cambridge University Press, 3 July 2017.

Keywords: Inflation Targeting, Exchange Rate, Indeterminacy, Asset Market Participation, Taylor Principle

As originally published the first keyword in this list was misspelled. The publisher regrets the error and displays the keywords correctly here:

Keywords: Inflation Targeting, Exchange Rate, Indeterminacy, Asset Market Participation, Taylor Principle

\section{REFERENCE}

Buffie, Edward F. and Zanna, Luis-Felipe (2018) Limited asset market participation and determinacy in the open economy. Macroeconomic Dynamics 22, 1937-1977. https://doi.org/10.1017/ S1365100516000961 